\title{
STRATEGI PEMASARAN BATIK LABAKO UD. BINTANG TIMUR DI DESA SUMBERPAKEM KECAMATAN SUMBERJAMBE KABUPATEN JEMBER
}

\author{
Hayik Heditullah ${ }^{1}$, Retna Ngesti Sedyati ${ }^{1}$, Sukidin ${ }^{1}$ \\ ${ }^{1}$ Program Studi Pendidikan Ekonomi, Fakultas Keguruan dan Ilmu Pendidikan, Universitas Jember
}

\begin{abstract}
This study aims to describe how the marketing strategy of batako labako done UD. Bintang Timur in Sumberpakem village Sumberjambe district Jember district. The type of research used in this study is qualitative. Place of study is determined by purposive area, that is Sumberpakem village Sumberjambe Sub district Jember. Informants used in this study are owners and employees. The Eastern Star will provide the information needed by the researcher. Furthermore, the additional informant in this research is the buyer or customer or agent of UD. Bintang Timur. The data in this study were obtained by document, interview and observation. Data analysis used in this research is data reduction, data presentation, and withdrawal conclusion done interactively and continuously. The end result of this research can be concluded that in selling or marketing its products, this company uses marketing strategy by focusing on promotion or promotion, in which related to advertising, sales promotion, and personal selling. First on the process of advertising is used two kinds of media that is, using the brochure media in spread or given to the community for free, and through the media business cards given to buyers or prospective buyers directly ditoko UD. Bintang Timur. Both sales promotions are made by this company through trade shows, product displays, purchase pieces. And the third personal sale is done by displaying his batik products neatly in a storefront located in UD Bintang Timur.
\end{abstract}

\section{Keywords: Marketing Strategy, Batik Labako UD. Bintang Timur}

\section{PENDAHULUAN}

Seiring dengan pertumbuhan ekonomi dan perkembangan teknologi, maka dunia usahapun mengalami perkembangan yang pesat dengan munculnya berbagai perusahaan yang berusaha menciptakan produk dan jasa guna memenuhi kebutuhan dan keinginan konsumen.

Membahas mengenai strategi pemasaran, semua perusahan tentu melakukan promosi untuk memasarkan atau menjual produknya. Menurut Kotler (2008:6) pemasaran adalah suatu proses sosial dan manajerial yang didalam individu dan kelompok mendapatkan apa yang mereka butuhkan dan inginkan dengan menciptakan, menawarkan dan mempertukarkan produk yang bernilai dengan pihak lain. Menurut David Downey (2000:3) pemasaran di definisikan sebagai telaah terhadap aliran produk secara fisik dan ekonomik dari produsen melalui pedagang perantara sampai ke tangan konsumen. Sedangkan penjualan menurut Kertajaya (2006:15) mengemukakan bahwa penjualan merupakan bagaimana menciptakan hubungan dengan pelanggan melalui produk atau jasa perusahaan, selling berarti sebuah taktik yang dapat mengintegrasikan perusahaan, pelanggan, dan relasi antara keduanya. Sedangkan menurut Basu Swasta $(2001 ; 1)$ dalam bukunya Manajemen Penjualan edisi ketiga, yaitu: menjual adalah ilmu dan seni mempengaruhi pribadi yang dilakukan oleh penjual untuk mengajak orang lain agar bersedia membeli barang dan jasa yang ditawarkan.

Perusahaan melakukan pemasaran suatu produk tentu membutuhkan promosi untuk memperkenalkan produk tersebut kepada konsumennya, promosi itu sendiri merupakan salah satu unsur dari bauran pemasaran (markeing mix) yaitu product, price, place, dan promotion (kotler dan amstrong, 2004:78). Promosi sangat berpengaruh terhadap usaha perusahaan untuk mencapai penjualan yang maksimal, karena meskipun produk yang ditawarkan sudah baik, relatif murah serta mudah untuk diperoleh, jika tidak disertai promosi yang baik, maka tingkat 
penjualan tidak akan memadai. Efektivitas promosi juga sangat tergantung dari pemilihan bentuk promosi yang diperlukan terhadap produk yang dipasarkannya. Suatu jenis produk tertentu memerlukan bentuk promosi tertentu pula, dengan kata lain tidak semua bentuk promosi dapat cocok dan menjamin keberhasilan promosi tersebut apabila tidak sesuai dengan kondisi yang dimiliki oleh suatu produk. Oleh karena itu, harus dicari suatu bentuk promosi yang sesuai dengan kondisi suatu produk yang akan dipromosikan terhadap barang yang dipasarkan dalam bentuk barang maupun jasa.

Efektivitas promosi juga sangat tergantung dari pemilihan bentuk promosi yang diperlukan terhadap produk yang dipasarkannya. Suatu jenis produk tertentu memerlukan bentuk promosi tertentu pula, dengan kata lain tidak semua bentuk promosi dapat cocok dan menjamin keberhasilan promosi tersebut apabila tidak sesuai dengan kondisi yang dimiliki oleh suatu produk. Oleh karena itu, harus dicari suatu bentuk promosi yang sesuai dengan kondisi suatu produk yang akan dipromosikan terhadap barang yang dipasarkan dalam bentuk barang maupun jasa.

Seperti halnya UD. Bintang Timur yang bertempat di J1. Raung No. 30 Sumberpakem, Sumberjambe Kabupaten Jember - Jawa Timur, perusahaan ini bergerak dibidang konveksi yang menghasilkan Batik khas Kabupaten Jember yaitu Batik Labako. Batik Labako tersebut merupakan simbol Kabupaten Jember sebagai Kota Tembakau sehingga Batiknya pun bermotif menyerupai daun tembakau, Batik itu sendiri merupakan pakaian khas dari masyarakat Indonesia, dan oleh UNESCO telah ditetapkan sebagai warisan budaya dunia (www.id.wikipedia.org/wiki/batik). Di Kota Jember saat ini pula Batik Labako sangat digemari oleh masyarakat Jember khususnya dan merupakan aset bagi Kabupaten Jember yang memberikan input bagi masyarakat produsen. Perusahaan dalam hal ini mampu menciptakan daya saing starategis yang berkelanjutan, salah satunya yaitu melalui strategi promosi penjualan yang akan digunakan oleh perusahaan. Strategi promosi penjualan yang diterapkan mengarahkan perusahaan dalam menetapkan keputusan-keputusan yang dianggap tepat bagi perusahaan. Dalam melakukan promosi penjualannya UD. Bintang Timur menawarkan kepada konsumenya dengan beberapa jenis produk kain batik yang diproduksi, diantaranya yaitu kain berbahan Katun dan kain berbahan Sutera. Untuk harga yang ditawarkanpun juga bervariasi, selain menyesuaikan jenis kain, juga menyesuaikan desain batik atas permintaan konsumen. Omset penjualan setiap bulannya UD. Bintang Timur memenuhi pesanannya sekitar 20 sampai 100 lembar perbulannya.

Permasalahan dalam penelitian ini adalah adanya persaingan produk dari perusahaan sejenis sehingga menyebabkan konsumen dapat berpindah pada perusahaan lain. Pesaing Perusahaan ini juga memproduksi batik tulis dan juga diuntungkan dengan lokasi perusahaan yang berdekatan dengan pusat kota sehingga besar kemungkinan untuk menjual atau memasarkan produknya lebih mudah dilakukan. Dengan demikian, industri Batik Labako UD. Bintang Timur ini dituntut untuk meningkatkan strategi penjualan yang lebih optimal agar dapat memenuhi kebutuhan konsumen sehingga usaha ini tidak kalah bersaing di pasar.

Berdasarkan latar belakang tersebut di atas, maka peneliti tertarik untuk melakukan penelitian yang berjudul "Strategi Pemasaran Batik Labako UD. Bintang Timur Di Desa Sumberpakem Kecamatan Sumberjambe Kabupaten Jember". 


\section{METODE PENELITIAN}

Penelitian ini dirancang sebagai penelitian deskriptif dengan pendekatan kualitatif untuk mendeskripsikan untuk mendeskripsikan bagaimana strategi pemasaran batik labako yang dilakukan UD. Bintang Timur di desa Sumberpakem kecamatan Sumberjambe kabupaten Jember.

Informan yang digunakan dalam penelitian ini adalah pemilik dan karyawan UD. Bintang Timur yang akan memberikan informasi yang dibutuhkan oleh peneliti. Selanjutnya yang menjadi informan tambahan dalam penelitian ini adalah para pembeli atau pelanggan maupun agen UD. Bintang Timur.

Data dalam penelitian ini diperoleh dengan dokumen, wawancara dan observasi. Analisis data yang digunakan dalam penelitian ini adalah Reduksi data, penyajian data, dan penarikan kesimpulan yang dilakukan secara interaktif dan berlangsung secara terus menerus.

\section{HASIL DAN PEMBAHASAN}

\section{Hasil Penelitian}

Promosi terdiri dari periklanan penjualan pribadi promosi penjualan dan publisitas. Namun, pada UD. Bintang Timur promosi pada publisitas tidak sepenuhnya digunakan, karena menyesuaikan kondisi usaha.

Kegitan promosi yang dilakukan UD. Bintang Timur yang pertama dengan cara menggunakan iklan. UD. Bintang Timur menjadikan iklan sebagai cara memperkenalkan batik labako kepada masyarakaat atau konsusmennya melalui media, seperti brosur dan kartu nama.

Brosur, Iklan dengan melalui brosur dipilih UD. Bintang Timur untuk menarik minat konsumen melalui berupa koleksi tampilan gambar batik labako sebagai contoh produksinya. Gambar batik ditampilkan dengan berbagai macam warna kain, motif-motif yang bervariasi namun tetap dipadukan dengan motif tembakau dan juga dengan harga yang bervariasi pula. Pada brosur tersebut juga tertera alamat maupun nomer telepon UD. Bintang Timur. Dengan seperti itu diharapkan mampu memudahkan dan mejangkau semua masyarakat atau konsumen dalam melakukan pemesanan maupun bisa langsung datang ke alamat UD. Bintang Timur yang telah tertera pada brosur.

Kartu nama, Penggunaan kartu nama yang digunakan oleh UD. Bintang Timur sebenarnya hampir sama dengan brosur yaitu memberikan informasi mengenai keberadaan tempat usaha batik labako UD. Bintang Timur. Namun, pada kartu nama tidak disertai dengan harga-harga lengkap batik tersebut. Dalam kartu nama ini hanya dicantumkan alamat, nomor telepon, gambar batik dengan ukuran kecil serta memberitahukan bahwa UD. Bintang Timur ini juga menerima pesanan eceran dan partaian. Dengan tujuan agar lebih memudahkan konsumen mengetahui alamat batik labako dan juga adanya nomor telepon yang tertera pada kartu nama lebih memudahkan konsumen apabila akan melakukan pembelian kembali setelah sebelumnya telah pernah melakukan pembelian.

Kegitan promosi yang dilakukan UD. Bintang Timur yang kedua yaitu promosi penjualan, promosi penjualan yang dilakukan UD. Bintang Timur merupakan kegiatan promosi yang berupa pameran dagang, display barang dan pemberian potongan penjualan.

Pameran dagang, Kegiatan pameran dagang yang dilakukan UD. Bintang Timur biasanya merupakan pameran yang di adakan oleh pemerintah kabupaten Jember baik diluar 
kota maupun didalam kota Jember. Pada saat pameran itu berlangsung UD. Bintang Timur juga melakukan display produk yaitu menampilkan semua produk batiknya sebagai daya tarik untuk para pembeli maupun calon pembeli. hal tersebut sesuai dengan hasil wawancara deng infoman utama penelitian, bahwa:

Biasanya kami diundang bupati untuk mengikuti acara Jember Expo di Kaliwates, dan bazar JFC (M, 47 tahun).

Pernyataan tersebut juga didukung oleh hasil wawancara dengan karyawan UD. Bintang Timur, bahwa:

Banyak juga orang-orang yang tau batik labako dari pas waktu dipameran Jember, dan mau datang kesini sumberpakem (SH. 36 tahun).

Pameran dagang yang ikuti UD. Bintang Timur untuk memasarkan batik labako kebanyakan merupakan event yang di adakan pemerintah Kabupaten Jember, seperti: Jember Expo, dan Jember Fashion Carnaval. Pameran dagang ini bahkan menjadi daya tarik tersendiri terhadap konsumen yang ingin datang langsung ketempat produksi batik labako yang berada di Desa Sumberpakem Kecamatan Sumberjambe.

Display produk, Display produk UD. Bintang Timur dilakukan ditempat usaha dengan menampilkan produk batik yang bermacam-macam motif yang disusun rapi didalam etalase dan adapula yang ditampilkan dalam bentuk baju kemeja. Hal itu dilakukan untuk memudahkan konsumen memilih motif batik yang akan dipesan ataupun dibeli. Pajangan atau display produk batik labako yang telah menjadi pajangan mempunyai koleksi yang bermacam-macam motif. Sesuai dengan hasil wawancara peneliti dengan karyawan, bahwa:

Disini kami menyediakan banyak macam motif batik labako, bisa lihat dari etalase langsung. Ada juga motif batik labako yang sudah jadi kemeja lengan pendek, ada juga lengan panjang ( $\mathrm{SH}, 37$ tahun).

Pernyataan tersebut juga didukung oleh hasil wawancara dengan pembeli batik labako UD. Bintang Timur, bahwa:

Waktu membeli batik labako saya di tawarkan contoh motif batik labako yang sudah jadi yang diletakkan di pajang di etalase (MS. 23 tahun)

Display produk batik labako pada UD. Bintang Timur dipajang pada etalase yang ada didalam toko, hal itu dilakukan agar konsumen bisa melihat contoh batik labako yang telah jadi, dan juga bisa dijadikan acuan bagi konsumen untuk memilih motif batik labako yang akan dipesan.

Potongan pembelian, Potongan pembelian yang dilakukan UD. Bintang yaitu dengan cara memberikan potongan kepada konsumen yang membeli batik dalam jumlah banyak atau partaian. Hal ini dilakukan UD. Bintang Timur tidak lain merupakan sebagai bentuk penghargaan kepada konsumen atas pembelian dalam jumlah lebih dari satu helai batik dan juga untuk menjaga hubungan baik dengan konsumen agar tetap kembali membeli batik ke UD. Timur sebagai pelanggan. Hal ini berdasarkan wawancara penelitian dengan pemilik, karyawan, dan pelanggan UD. Bintang Timur, bahwa:

Potongan harga biasanya saya berikan ke yang membeli batik lebih dari dua helai kain, kadang saya beri potongan kelipatan harga (M, 46 tahun).

Pernyataan tersebut didukung oleh hasil wawancara dengan karyawan UD. Bintang Timur, bahwa: 
Orang yang membeli kain batik misalnya batik harga 35 ribu membeli 4 helai, diberi potongan 5 ribu perhelai kain batik (SH, 36 tahun).

Pernyataan tersebut juga didukung oleh hasil wawancara dengan pelanggan UD. Bintang Timur, bahwa:

Saya waktu itu diberikan potongan harga perhelai kain dengan potongan harga 5ribu (MS, 23 tahun)

Potongan pembelian yang dilakukan UD. Bintang Timur sebenarnya tujuannya untuk menciptakan pelanggan, dan juga merupakan bentuk penghargaan kepada konsumen atas pembelian dalam jumlah lebih dari satu helai, hal tersebut setidaknya bisa menjaga hubungan baik dengan konsumen agar tetap kembali membeli batik labako UD. Timur.

Kegitan promosi yang dilakukan UD. Bintang Timur yang ketiga yaitu penjualan pribadi, Proses penjualan pribadi dilakukan oleh UD. Bintang secara bertatap muka langsung (face to face) antara penjual dengan pembeli, pada saat pembeli mendatangi toko UD. BintangTimur, penjual meyakinkan produk yang ditawarkan kepada konsumen dengan memberikan berbagai contoh batik yang telah menjadi pajangan atau display produk yang ada ditoko tersebut.

Berdasarkan strategi pemasaran yang berfokus pada promosi yang dilakukan UD. Bintang Timur tersebut, masyarakat sudah banyak mengerti tentang batik labako, semakin banyak masyarakat datang ke tempat UD Bintang Timur dan juga semakin banyak pesanan yang diterima oleh UD Bintang Timur. Hal ini diperkuat dengan hasil wawancara yang dilakukan oleh peneliti kepada pemilik dan karyawan UD Bintang Timur:

Pesanan yang kami terima dalam seminggu kurang lebih 50 sampai 100 helai kain

batik, itu masih belum terhitung yang memesan partaian, biasanya yang pesan partaian lebih dari sekitar 20 helai batik (M, 46 tahun).

Pernyataan tersebut juga didukung oleh hasil wawancara dengan karyawan UD. Bintang Timur, bahwa:

Yang datang kesini itu tidak hanya dari Jember saja. Dari bondowoso, Situbondo,

Lumajang, Banyuwangi, Malang, Bali dan Bahkan turis yang biasa berliburi ke Bali mampir kesini (SH, 37tahun)

Pernyataan tersebut juga didukung oleh hasil wawancara dengan pembeli UD. Bintang Timur, bahwa:

orang yang menjual batik labako ditoko, menemui saya dengan sangat ramah sekali, selain diperlihatkan semua contoh batiknya, saya selalu disarankan bagaimana desain motif batik labako yang bagus (AF, 27 tahun)

Strategi pemasaran yang dilakukan UD. Bintang Timur terdiri dari iklan, promosi penjualan dan penjualan pribadi terbagi kedalam beberapa bentuk media yang digunakan untuk memasarkan produk batik labako kepada masyarakat terdiri dari brosur, kartu nama, pameran dagang, display produk dan potongan penjualan. Hal tersebut dilakukan UD, Bintang Timur agar batik labako bisa diterima dengan baik di masyarakat dan untuk kelangsungan hidup perusahaan UD. Bintang Timur. 


\section{Pembahasan}

Hasil penelitian menunjukkan bahwa promosi batik labako UD. Bintang Timur yaitu:

Pertama, promosi pada periklanan dilakukan oleh perusahaan dengan cara penyebaran selebaran brosur yang dilakukan UD. Bintang Timur kepada masyarakat diberikan secara cumacuma dan kartu nama diberikan pada konsumen pada saat datang langsung ditempat produksi batik labako atau pada saat melakukan pembelian dengan tujuan menjaga hubungan dengan konsumen.

Kedua merupakan promosi penjualan, berdasarkan hasil penelitian, strategi pemasaran yang telah dilakukan UD. Bintang Timur pada promosi penjualan meliputi pameran dagang, display produk dan pemberian potongan pembelian. Pameran dagang merupakan kegiatan untuk memperkenalkan dan mempromosikan batik labako kepada konsumen atau masyarakat. UD. Bintang Timur melakukan promosi penjualan seperti pameran yang diselenggarakan pemerintah Kabupaten Jember yaitu acara Jember Expo dan JFC (Jember Fashion Carnaval). Dalam acara Jember Expo dan JFC dapat digunakan oleh UD. Bintang Timur sebagai ajang untuk memperkenalkan produk batik labako kepada konsumen. Sesuai seperti yang dikemukakan oleh Assauri (2007:282), bahwa promosi penjualan merupakan kegiatan pemasaran yang merangsang pembelian oleh konsumen dan keefektifan agen seperti pameran atau pertunjukan. Selanjutnya display produk UD. Bintang Timur dilakukan ditempat usaha dengan menampilkan produk batik yang bermacam-macam motif yang disusun rapi didalam etalase dan adapula yang ditampilkan dalam bentuk baju kemeja. Hal itu dilakukan untuk memudahkan konsumen memilih motif batik yang akan dipesan ataupun dibeli. Selain mengikuti pameran dagang dan melakukan display produk, salah satu bentuk promosi penjualan lainnya yang digunakan oleh UD. Bintang Timur adalah dengan memberikan potongan harga kepada konsumen yang melakukan pembelian batik. Hal ini dilakukan oleh UD. Bintang Timur sebagai salah satu cara untuk memkberikan kepuasan kepada pelanggan maupun pembeli pemula agar memiliki kesan baik sehingga konsumen akan melakukan pembelian ulang.

Ketiga merupakan penjualan pribadi, bentuk dari penjualan pribadi atau personal selling tersebut dilakukan UD. Bintang Timur tidak digunakan secara bersama-sama dan kadang hanya menggunakan salah satu bentuk saja. Hal tersebut disesuaikan dengan kondisi dan kemampuan perusahaan. Strategi pemasaran yang dilakukan UD. Bintang Timur merupakan kegiatan promosi untuk menjual batik labako meliputi iklan, promosi penjualan dan penjualan pribadi, agar batik labako dikenal masyarakat, lebih diminati di masyarakat dan juga UD. Bintang Timur bisa bersaing dengan produsen batik lain secara baik. Penjualan pribadi yang dilakukan oleh UD. Bintang secara bertatap muka langsung (face to face) antara penjual dengan pembeli, pada saat pembeli mendatangi toko UD. BintangTimur, penjual meyakinkan produk yang ditawarkan kepada konsumen. hal ini sesuai pendapat Djasmin Saladin (2004:195), yaitu: tenaga penjual melakukan penjualan dengan jalan melayani konsumen yang datang ketoko atau perusahaan. tenaga penjual yang melakukan penjualan diluar perusahaan, yakni dengan mendatangi konsumen kerumah-rumah, kantor-kantor dan lain-lain. pimpinan perusahaan yang bertindak sebagai tenaga penjual yang melakukan penjualan. 


\section{KESIMPULAN DAN SARAN}

\section{Kesimpulan}

Hasil akhir dari penelitian ini dapat disimpulkan bahwa dalam menjual atau memasarkan produknya, perusahaan ini menggunakan strategi pemasaran dengan berfokus pada promotion atau promosi, yang didalamnya berhubungan dengan periklanan, promosi penjualan, dan penjualan pribadi. Pertama pada proses iklan tersebut digunakan dua macam media yaitu, menggunakan media brosur yang di sebar atau diberikan kepada masyarakat secara gratis, dan melalui media kartu nama yang diberikan kepada pembeli atau calon pembeli secara langsung ditoko UD. Bintang Timur. Kedua promosi penjualan yang dilakukan oleh perusahaan ini melalui pameran dagang, display produk, potongan pembelian. Dan yang ketiga penjualan pribadi yang dilakukan dengan memajang produk batiknya secara rapi dalam etalase yang berada ditoko UD. Bintang Timur.

\section{Saran}

Berdasarkan kesimpulan tersebut, maka saran yang dapat diberikan berkaitan dengan penelitian antara lain adalah: Pemilik UD. Bintang Timur hendaknya membuat iklan melalui media web agar lebih memudahkan konsumen mengetahui secara online koleksi batik labako yang lebih, karena dengan media web bisa memuat atau menyimpan banyak gambar dan tulisan, pada kegiatan promosi penjualan, selain mengikuti event atau bazar maupun pameran dagang yang dilakukan pemerintah kabupaten.

\section{DAFTAR BACAAN}

Assauri (2007) Peramalan Penjualan. Yogyakarta: Penerbit Fakultas Ekonomi UGM.

David, downey (2002) manajemen agribisnis. Buku keempat. Erlangga. Jakarta.

Djasmin Salamin (2004) Manajemen Pemasaran/ Linda Karya. Bandunng.

Kertajaya, hermawan (2006) elemen marketing. seri 9. Mizan. Jakarta.

Kotler dan Amstrong (2004) Dasar-dasar pemasaran. Edisi kesembilan. PT. Indeks. Jakarta.

Kotler dan amstrong (2008) prinsip-prinsip pemasaran. Edisi seduabelas. PT. Indeks. Jakarta.

Swasta, basu (2001) manajemen pemasaran edisi ketiga. Erlangga. Jakarta. 